\title{
Protestantisme med kød og blod
}

\author{
Professor Niels Henrik Gregersen
}

\begin{abstract}
In this article, "Protestantism with blood and flesh", it is argued that a Lutheran theology cannot and should not be reduced to general Protestant principles. Luther's theology emerged as a result of renewed attentiveness to the basic expressions of the gospel: the audible word of God, the visible sacraments, the bodily aspects of communal li$\mathrm{fe}$, and the evangelical signs of creation. The so-called Protestant Principles, at their best, are to be regarded as second-order and summarizing expressions of the primary life-utterances of the church, and of the corresponding experiences in ordinary life. Moreover, at a closer inspection the exclusive particles such as solo Christo and sola fide are to be taken as inclusive particles that provide a participation in God, enacted in faith, hope and love.
\end{abstract}

Key words: Martin Luther - Protestant principles - Friedrich Schleiermacher - theology of creation - liturgy - sacraments.

\section{Indledning}

Med titlen, "Protestantisme med kød og blod", er der antydet, at der også findes en protestantisme uden kød og blod. En sådan protestantisme uden kød og blod kender vi fra den nyprotestantisme, der ønskede at grundlægge religionen på menneskets bevidsthed frem for på dets stilling i verden. Med titlen er der derfor indirekte annonceret det normative synspunkt, at mens sidstnævnte er en lige lovlig blodfattig affære, så drejer det sig i dag om at reformulere en evangelisk kristendom med en anderledes sans for krop og socialitet. Med "kød og blod" tænker jeg her ikke i første række på den fysiologiske krop, men på det forhold, at også en reformatorisk teologi ved, at mennesket er indlejret $\mathrm{i}$ en verden fyldt af betydninger. Verden kommer mennesket i møde i den sociale verden i form af en betydningsverden (en semantik), hvori ord og tegn og gestik har lige så stor betydning som de faktiske ting, der sker i os og omkring os. En protestantisme med kød og blod er altså en evangelisk teologi, der er sig bevidst, at vore teologiske fortolkninger ikke kan løsgøres fra tilværelsens førsproglige tegn og kropsbaserede menneskelige ytringer. En protestan- 
tisme med kød og blod tænker kristendommen på det vilkår, at vi som kropslige væsener ikke i længden kan leve og overleve på principper og formalistiske fortolkningsnøgler. Vi lever ikke bare inden for vore egne organismers biologiske skind (skind med d!), men fyldes til stadighed af en omverden, der berører os, og formes af budskaber, der på en gang er helt ikonisk tæt på, fordi de rammer os i vores eksistentielle betydningsdannelse, men som samtidig viser bort fra sig selv, for så vidt som der bringes bud om det, man ikke kan se med det blotte øje eller røre ved med de kropslige sanser.

Jeg vil i det følgende kun give ganske enkelte eksempler på, hvordan denne kropslighed er tænkt ind i Luthers teologi. Min underliggende forudsætning vil være, at de sider af Luthers teologi, som har at gøre med forbindelsen mellem det ydre og det indre, kan reformuleres i lyset af Charles Sanders Peirces tegnteori. Når det drejer sig om tegnets relation til ydre objekter, skelner Peirce mellem ikonet, hvor der er en lighed mellem det, der siges eller gøres, og det som man vil sige noget om (man kan tænke på velsignelsen som gestus), og indexet, hvor tegnet bruges til at henvise til noget andet (som når et løfte henviser til en fremtidig realitet, hvis ankomst annonceres af tegnet), og endelig symbolet, som rummer en mere generel (lovmæssig eller konventionel) relation mellem et sæt af ord eller billeder og et andet sæt af objekter (man kan tænke på brød og vin som betegnelsen for Kristi legeme og blod i nadverhandlingen). Sådanne symbolers betydning er knyttet til fortolkningsfællesskaber, som i Luthers tilfælde er menigheden. Som man her vil se, vil et symbol altid involvere et slags index (for så vidt som det refererer til et objekt, som det er bestemt af), ligesom et index som regel vil indeholde en vis ikonisk kvalitet i forhold til det, som det henviser til. ${ }^{1}$ Peirces tegnteori vil således kunne anvendes som en almen filosofisk ramme, inden for hvilken Luthers tale om forholdet mellem tegnet, sagen og troens brug deraf (signum, res, usus) vil kunne ekspliceres filosofisk. ${ }^{2}$ Selvom Luther ikke selv mente, at filosofien havde noget fornuftigt at sige om troen (filosofi var for ham identisk med aristotelisme), så kan en pragmatistisk tegnteori a la Peirces tjene til at afklare selve strukturen i Luthers tegnteori. Det skyldes, at der hos Luther både er en ikonisk nærhed mellem ord og virkelighed (som er afgørende for Luthers sakramentsforståelse) og en forståelse af, at tegn i almindelighed hand-

1. Charles Sanders Peirce, "Nomenclature and Divisions of Triadic Relations, as Far as They Are Determined" (1903), i The Essential Peirce. Selected Philosophical Writings. Volume 2 (1893-1913), ed. The Peirce Edition Project (Bloomington: Indiana University Press 1998), 289-299 (291f).

2. Se hertil Gesche Linke, Zeichen und Gewissheit. Semiotische Entfaltung eines protestantisch-theologischen Begriffs (Tübingen: Mohr-Siebeck 2010). 
ler om noget fraværende og fremtidigt, som ordet giver løfte om. Der vil altid være et element af constitutive absence i et materielt tegn, der viser hen til noget mere alment eller noget fremtidigt. ${ }^{3}$ Eller som Peirce selv formulerede det: "The rational meaning of every proposition lies in the future". 4

\section{Protestantisme med kød og blod}

Man skal ikke have læst mange sider af den unge Luthers sakramentsteologi, før man støder ind i treklangen af tegn (lat. signum, ty. tzeychen), sag (lat. res, ty. bedeutung) og troens brug (lat. utilitas, ty. geprauch). Tegnet omfatter det ydre, men ikke kun vandet (for dåbens vedkommende) eller brødet og vinen (for nadverens vedkommende), men også det ydre ord og den ydre sociale handling, som elementerne indgår i. Om dåben hedder det fx: "Tegnet består deri, at man i Faderens, Sønnens og Helligåndens navn fører mennesket ud i vandet; men man lader ham ikke blive der, men drager ham atter op... Dåbens tegn må således indeholde begge dele: at vi dykkes ned og drages op" 5 Tegnet er altså ikke det fysiske element alene, men hele dåbshandlingen. Den samme understregning af tegnets socialitet finder vi nadversermonen fra 1519. Her drejer det sig igen ikke kun om brødet og vinen som nadverens ydre form og skikkelse, men om at vi "nyder brødet og vinen ved at spise og drikke". ${ }^{6}$ Tegnet er hele måltidet med de dertil hørende ord af Kristus, ikke kun "elementet". Men pointen er samtidig, at selve sagen (res) eller betydningen (bedeutung) og gerningen (werck) rækker ud over den synlige handling, fordi den viser ind i hele den livshistorie, som mennesket har til Gud og Gud til mennesket. Men denne lange livshistorie er for nærværende just fraværende, fordi mennesket først endegyldigt vil afdø fra synden gennem døden. "Betydningen er det salige, at synden dør, og vi opstår ved Guds nåde, så det gamle menneske, som er undfanget og født i synd, drukner, og et nyt menneske fremgår og opstår født i nå-

3. Om begrebet "constitutive absence" (i forlængelse af C.S. Peirce), se Terrence W. Deacon, "What is Missing from Theories of Information?", i Information and the Nature of Reality: From Physics to Metaphysics, eds. Paul Davies og Niels Henrik Gregersen (Cambridge: Cambridge University Press 2010), 146-169.

4. Charles Sanders Peirce, "What Pragmatism Is" (1905), i The Essential Peirce. Volume 2, 331-345 (340).

5. Martin Luther, "En sermon om dåbens hellige, ærværdige sakramente" (1519), Luthers skrifter $i$ udvalg I, red. Niels Nøjgaard (København: Gad 1962), 113-126 (114).

6. Martin Luther, "En sermon om Kristi legemes sakramente og om broderskaberne" (1519), Luthers skrifter i udvalg I, 129-149 (129). 
de". ${ }^{7}$ Luther fremhæver i samme forbindelse, at mens selve dåbshandlingen (tegnet) kun varer et øjeblik, så virkeliggøres betydningen ikke fuldt ud i dette liv, men "varer ved, så længe vi lever, og fuldbyrdes ikke før end i døden, og dér sker det, dåben betyder. Derfor er hele dette liv intet andet end en uafladelig åndelig dåb, indtil døden indtræffer". ${ }^{8}$ Helt parallelt gælder det for nadverens betydning, at den indstifter et fællesskab med Kristus og alle andre troende, som rækker ud over døden. Nærvær og fravær betinger således hinanden: Kristi reale nærvær er forudsætningen for den fremtidige historie, hvori Kristus aldrig er alene, men altid er sammen med sine troende.

Mens dåben er sakramentet for hele individets livshistorie, er nadveren fællesskabets sakramente, fordi det er "kærlighedens sakramente": "Dette sakramentes betydning [bedetung] eller gerning [werck] er alle helliges fællesskab. Derfor er dets gængse navn også synaxis eller communio, det vil sige fællesskab, ... og det navn kommer af, at Kristus med alle de hellige udgør ét åndeligt legeme". ${ }^{9}$ Der er altså en særlig rumlig sans knyttet til nadveren, fordi nadveren viser ind i kærlighedens fællesskab med kristne og alle troende, ligesom der var en overvejende tidslig horisont knyttet til dåben, da dåbens mening først fuldbyrdes i døden, hvor den gamle Adam omsider dør fuldstændigt for at blive forvandlet til den nye Adam ved opstandelsens nåde.

Alt dette betyder på ingen måde, at kun det ydre, synlige og legemlige har betydning. Tværtimod er skal det ydre tegn tjene til at gøre det åndelige fællesskab med Kristus nærværende, selvom dette endnu ikke er synligt til stede. I forbindelse med dåben var det primært troen, der stod i centrum, eftersom troen forbinder tegnet og sagen, idet der ved dåben stiftes en forbindelse mellem mennesket og Gud: "dåbens højværdige sakramente gavner dig derved, at Gud ved den forbinder sig med dig og bliver ét med dig i en nådig og trøsterig pagt". ${ }^{10}$ Men en forbindelse har altid to sider. Mens Gud gennem sakramentet forbinder mennesket med sig selv, er det fra menneskets side troen, der skaber foreningen med Gud, idet troen "forbinder os med Gud, så vi indtil døden vil døde synden og stride mod den". ${ }^{11}$ På samme måde er kærligheden det, der forbinder det kristne menneske med Gud, idet nadverens sakramente er "kærlighedens og enighedens sakramente”. ${ }^{12}$ Men også her gælder, at kærligheden først når sit

7. Martin Luther, "En sermon om dåbens hellige, ærværdige sakramente", 114.

8. Ibid., 114-115.

9. Martin Luther, "En sermon om Kristi legemes sakramente og om broderskaberne", 133 og 130.

10. Martin Luther, "En sermon om dåbens hellige, ærværdige sakramente", 117.

11. Ibid., 119.

12. Martin Luther, "En sermon om Kristi legemes sakramente og om broderskaberne", 140. 
mål, når den er gensidig: "ligesom der skænkes dig kærlighed og bistand, således må du igen vise Kristus kærlighed og bistand ved at hjælpe hans trængende brødre". ${ }^{13}$ Nadverens mening kan således ikke uddestilleres fra det ydre tegn, dvs. fra nadvermåltidets hele sammenhæng. Sakramentets betydning kan ikke fas i rent sproglig form, der kan formuleres i enkelte sætninger, ligesom sakramentets mening ikke kan ejes som en fritsvævende åndelig indstilling. Nadveren har slet ikke nogen gavn eller virkning, hvis mennesket isolerer sit forhold til Gud fra fællesskabet med de nødlidende: "thi hvor kærligheden ikke daglig vokser og forvandler mennesket således, at han har fællesskab med enhver, dér findes dette sakramentes frugt og betydning ikke". ${ }^{14}$

Men under alt dette er det Luther sjælesørgeriske pointe, at man ikke skal tage temperatur på sin egen tros inderlighed eller på sin egen kærligheds kraft. Her er det ydre atter af betydning. For som Luther siger det i sin Sermon om beredelsen til at dø, så gælder det om at holde sig til ordet og de ydre tegn, hvorimod man ikke skal bekymre sig om graden af egen tro, om sine egne synders vægt: : "Thi i sakramenterne handler, taler og virker din Gud, Kristus, selv med dig igennem præsten; og dér sker ikke menneskers gerninger eller ord, dér tilsiger Gud dig selv alle de ting, som nu er sagt om Kristus, og vil, at sakramenterne skal være et bevis på og en kundgørelse af, at Kristus har taget din død på sig og overvundet den, hans lydighed din synd, hans kærlighed dit helvede". ${ }^{15}$ Kort sagt: Kun gennem det ydre (tegnene) kommer vi til det indre (troen) og det indre (troen) vil altid komme til udtryk i det ydre (kærligheden), uden at vi er i stand til at følge vor bevidstheds bevægelser. For vi lever altid på et dybere niveau, end vi tænker.

Dette er, hvad jeg vil kalde en protestantisme med kød og blod. Det er ikke den fysiologiske krop, der står i centrum, men den sociale krop, som udgøres af fællesskabet med andre troende og med ethvert nødlidende menneske. Det er endvidere en protestantisme, der kun eksisterer, såfremt den leves; den kan ikke eksistere i en ren og skær bevidsthedsrelation til Gud. Det er derfor også en ganske krævende protestantisme, som er hinsides al konfessionalistisk selvgodhed. For det er den, der tror og yder, der er kristen, og hvem tør her stå frem som den, der strutter af tro og kærlighed i modsætning til "de andre".

13. Ibid., 133.

14. Ibid., 136.

15. Martin Luther, "En sermon om beredelsen til at dø" (1519), Luthers skrifter $i$ udvalg I, 96-111 (105). Se hertil Theodor Jørgensen, "Ord og billede hos Luther overvejet på grundlag af hans 'Sermon om beredelsen til at $\mathrm{d} ø$ '”, Korset $i$ altet (Frederiksberg: Anis 1995), 101-111. 
Det evangeliske anliggende, som kom frem i Luthers teologi, er derfor heller ikke lige til at skrive sammen til en "position" - og slet ikke til en minimalistisk protestantisme, hvis principper kan læres og tilegnes på tyve minutter.

I det følgende antager jeg, at Luther sagligt set ikke ændrer noget væsentligt ved sin triade mellem tegn, sag og betydning fra 1519-sermonerne. De ligger efter Luthers "reformatoriske gennembrud", hvis man følger Erwin Bizers eller Oswald Bayers påstand om, at der sker noget afgørende med Luthers teologi i 1518, hvor det ydre tegns løfte kommer til at stå i centrum, alt imens Luther fastholder Kristi præsens $\mathrm{i}$ ordet. ${ }^{16} \mathrm{Og}$ selvom det er rigtigt, at Luther i perioden 1520 1523 understreger det bibelske ord mere end de ydre sakramenter på grund af sin kritik af kirkens babyloniske fangenskab i samtidens katolske teologi, så står ordet som det ydre tegn (verbum externum), som både hørbart og synligt (audibile et visibile), fortsat i centrum, ligesom nadverens elementer, brød og vin, igen får en markant ny rolle i Luthers opgør med sværmerne og Zwingli i perioden 1523-1528.

Det er værd at bemærke, at Luthers udfoldelse af forholdet mellem tegn, betydning og brug svarer forbavsende godt til den struktur, som vi oven for fandt formuleret hos pragmaticisten C.S. Peirce: et $u d-$ sagns mening viser sig først i fremtiden, nemlig i fremtidens brug af tegnet og ordet, hvor betydningen vil komme til sin ret. På dette sted kan der være grund til at imødegå alt for ensidige tolkninger af Luthers tegnteori. Oswald Bayer har med rette fremhævet, at Luther med sine overvejelser over bodssakramentet overvinder Augustins antikke (stoisk-nyplatonske) lære om tegnet som noget, der henviser til noget fraværende eller bagvedliggende. ${ }^{17} \mathrm{I}$ en af sine bordtaler siger Luther således, at begrebet tegn i filosofien betegner noget fraværende, mens det i teologien betegner noget nærværende. ${ }^{18}$ Men Bayer tager heraf anledning til at mene, at den egentligt reformatoriske opdagelse ligger i den "deklaratoriske" sproghandling, "jeg forlader dig dine synder", nærmere bestemt i "det tilforladelige frelsestilsagn, den promissio der konstituerer frelsens vished". ${ }^{19}$ Men promissio betyder nu engang forjættelse og indeholder som sådan altid en relation til

16. Ernst Bizer, Fides ex auditu. Eine Untersuchung über die Entdeckung der Gerechtigkeit Gottes durch Martin Luther (Neukirchen-Vluyn: Neukirchener Verlag 1958); Oswald Bayer, Promissio. Geschichte der reformatorischen Wende in Luthers theologie (Göttingen: Vandenhoeck \& Ruprecht 1971).

17. Dette udgjorde allerede hovedtesen i Bayer, Promissio.

18. WA TR 4, 666 [1540]: Signum philosophicum est nota absentis rei, signum theologicum est nota praesentis rei”. Se hertil Oswald Bayer, Martin Luthers Theologie. Eine Vergegenwärtigung (Tübingen: Mohr-Siebeck 2003), 48.

19. Bayer, Martin Luthers Theologie, 47-48. 
den fremtidige historie mellem Gud og menneske, sådan som vi netop har set det i dåbsermonen fra 1519. Tilgivelsen i dåben er således ikke kun en bagudrettet ikke-tilregnelse af synden, men også en tilgift med fremadrettet virkning, indledningen til en ny historie mellem Kristus og den troende. Dåbens betydning virkeliggøres således først helt og fuldt, når den gamle Adam dør i menneskets sidste time og den nye Adam opstår ved Åndens kraft. Nærvær og fravær kan således ikke spilles ud mod hinanden hos Luther. Kristi nærvær i tegnet og ordet er således forudsætningen for Guds vej med mennesket og menneskets vej med Gud - livet igennem. Der findes ikke noget nøgent evangelium om Kristus solo, som ikke også indbefatter Kristus som den, der tager bolig i menneskets tro, håb og kærlighed. ${ }^{20}$

Luthers teologi om ordet og sakramenterne har ikke kun kød og blod i forbindelse med hans lære om ordet og sakramenterne. Kød og blod præger også den skabelsesteologi, som han udviklede i sine katekismer og prædikener. Efter at Luther havde gjort op med naturlige teologi (ikke mindst i Heidelbergteserne 1518), begyndte han ufortrødent at udfolde sin skabelsesteologi. Allerede i skriftet mod Emser fra 1521 kunne han sige, at "al Guds handlen og alle Guds skabninger er lutter levende tegn og Guds ord". ${ }^{21}$ Man skal ganske vist ikke finde Gud i naturen men i ordet og sakramenterne; man kan derfor ikke konstruere et rationelt argument fra verdens tilstand til Guds "eksistens"; Gud vil findes i ordet og i sakramenterne. Men det betyder ikke, at Guds virke er begrænset hertil. Set ud fra troen er hele verden "fuld af bibel". ${ }^{22}$ Denne tankegang udvikler Luther først og fremmest gennem sine prædikener, navnlig hans prædikener over Davids Salmer og Jesu forkyndelse. Der er for så vidt tale om et ganske enkelt budskab, som vi også kender det fra Lille og Store Katekismus, nemlig at Guds velvilje og barmhjertighed helt uden vor fortjeneste kanaliseres ind igennem skaberværket. Ligesom solen går op over både onde og gode (Mat 5, 45), er alle skabninger "kun de hænder, kanaler

20. Se hertil Karsten Lehmkühler, Inhabitatio. Die Einwohnung Gottes im Menschen (Göttingen: Vandenhoeck \& Ruprecht 2004), særligt 228-286.

21. Martin Luther, "Auf das überchristlich, übergeistlich und überkünstlichen Buch Bocks Emsers zu Leipzig Antwort”, WA 7, 614-698 (650): all gottis werck und creaturn [sind] eytel lebendig tzeychen und wort gottis.

22. Se hertil oversigten hos Dieter Groh, Schöpfung im Widerspruch. Deutungen der Natur und des Menschen von der Genesis bis zur Reformation (Frankfurt a.M.: Suhrkamp 2003), 541-598, med henvisning til bl.a. Anselm Steiger, "'Alles voll Bibel'. Die Predigt der Kreatur in der Theologie Martin Luthers. Oder: Die Sprachmacht des Gemachten”, i Barbara Bauer-Mahlmann ed., Scientiae et artes: Die Vermittlung alten und neuen Wissens in Literatur, Kunst und Musik (Wiesbaden: Harrassowitz Verlag 2004), 189-214. 
og midler, hvorigennem Gud giver det alt sammen, ligesom han giver moderen bryster og mælk for at give det til barnet...”. ${ }^{23}$

Luther kan derfor i sin forkyndelse af evangeliet tage sin begyndelse hvor som helst. I sakramenterne, i Jesu forkyndelse, i Paulus' breve, men også Davids salmer. David inviterer nemlig til "den skønne lovsang" (Das schöne Confitemini), som Luther kaldte sin store udlægning af Davids Salme 118 fra juli 1530. Allerede i fortolkningen af vers 1 ("Tak Herren, han er god, hans trofasthed varer evindelig") tager han udgangspunkt i skabelsens nåde. ${ }^{24}$ Gud beviser sin gunst over al måde til alle mennesker, hedder det, for "Han skaber vort legeme og vor sjæl, bevarer os dag og nat, holder os stadig i live, lader sol og måne skinne for os og himmelen, ild, luft og vand tjener os, lader vin, korn, foder, føde og klæder, træ og alt, hvad vi trænger til, vokse frem af jorden, giver guld og sølv, hus og gård, hustru og børn, kvæg, fugle og fisk, Kort sagt: hvem kan nævne det alt sammen? Og det alt sammen rigeligt og overstrømmende, hvert år, hver dag, hver time, hvert øjeblik." 25

Luthers pointe er, at det kun er på grund af synden, at vi ikke er i stand til at værdsætte og lovprise Guds godhed. Derfor kommer det heller til nogen "naturlig teologi" fra Luthers hånd. Ikke fordi naturen ikke kan udfoldes teologisk (for det er netop, hvad Luther gør i sin skabelsesteologi), men fordi vi er "blinde og ligegyldige og uagtsomme over for Guds gaver". Alligevel ligger der et slags argument hos Luther. Det er ganske vist ikke et argument, der fører ad fornuftens vej fra skaberværkets struktur til antagelsen af Gud. Men det er et argument, der viser den blindhed og tåbelighed, der ligger i menneskets synd, som ikke får øje for Guds overstrømmende gaver. Argumentet er, at vi i synden lever i en illusion, der er så gennemgribende, at vi end ikke opdager vor egen illusion:

Hvad er alverdens penge og gods imod et sundt legeme? Hvad er al verdens penge og gods imod én dag, som den kære sol dagligt skænker os? ... Hvad ville alle skønne slotte, huse, fløjl, silke, purpur, gyldne kæder og ædelstene være værd, al pragt, pynt og forfængelighed, hvis vi skulle undvære luften så længe, som det varer at bede et fadervor. Sådanne Guds goder er de største og de allermest ringeagtede, og fordi de er almindelige, er der ingen, der takker Gud for dem, men man tager dem og bruger dem daglig uden at tænke derover, som om det nødvendigvis

23. Martin Luther, Den store Katekismus (København: Credo 1996), 46.

24. Se hertil Niels Henrik Gregersen, "Grace in Nature and History: Luther's Doctrine of Creation Revisited", Dialog: A Journal of Theology 44:1 (2005), 19-29.

25. Martin Luther, "Den skønne lovsang, salme 118” (1530), Luthers skrifter $i$ udvalg III, red. E Thestrup Pedersen (København: Gad 1964), 261-335 (264). 
måtte være sådan, og vi ligefrem havde ret dertil og ikke engang behøvede at takke Gud for dem. ${ }^{26}$

For Luther var skabelsen ikke blot et foreliggende faktum, men Guds levende værk som mennesket får lod og del i. Verden er en tegnverden, der indeholder et budskab, som vi ikke kan lade være med at forholde os til - i troens taknemmelighed eller i negligeringens ligegyldighed. Ligesom planten strækker sig mod solens lys og dens rødder ned til jodens vand, sådan søger også mennesker mod lyset, drikker vand, når de er tørstige, søger hinandens selskab osv. Vi lever også som mennesker - kunne man sige - $\mathrm{i}$ en biosemiotisk verden, endda $\mathrm{i}$ en verden, som er biofysisk anlagt med henblik skabelse, videreførelse og vækst. Derudover lever vi i en menneskelig livsverden anlagt på fællesskab og omsorg; endelig lever vi et liv med-os-selv sammen med andre. Skabelsens verden er fuld af kød og blod, fordi vi i den lever både i naturens store kreds, i det sociale livs mellemsfære, og med os selv hver for sig - men aldrig alene. Som Luther udbryder: "Velan, du er jo dog en kærlig, god Gud, at du evindelig, dvs. stadig på ny og uden ophør, viser mig uværdige og utaknemmelige en så rigelig godhed og velgerning. Dig tilkommer lov og tak!"27

\section{Protestantismen uden kød og blod}

Vi vender os nu fra Luthers evangeliske teologi til ideen om en "protestantisk teologi". Lad mig begynde med at minde om, at vi her har at gøre med en betegnelse, som oprindeligt var en politisk fremmedbetegnelse, ikke en teologisk selvbetegnelse. På Rigsdagen i Speyer 1529 fremlagde de reformatoriske repræsentanter således en protestatio, hvori de påberåbte sig religionspolitisk selvstændighed ud fra den opfattelse, at "i sager, der drejer sig om Guds ære og den evige frelse, står hver enkelt over for Gud og må aflægge regnskab for sig selv". ${ }^{28}$. Herefter blev de og deres tilhængere kaldt protestantes af de romersk-katolske teologer. Reformatorerne betegnede derimod sig selv som de "evangeliske". For de ville defineres ud fra deres teologiske anliggende, som de selv mente var et fælles, "katolsk" anliggende for kirken som helhed. Formålet var således ikke at skabe en ny kirke, men at refor-

26. Ibid.,264-65.

27. Ibid.,265-266.

28. David W.Lotz, "Protestantism", The Oxford Encycklopedia of the Reformation vol 3, ed. Hans J. Hillerbrand (New York: Oxford University Press 1996), 351-357, der påpeger, at begrebet protestatio i samtiden ikke kun betød en nej-sigende protest, men også en højtidelig erklæring, hvori man bevidner sin position (352). 
mere kirken ved at kritisere misbrug og menneskelige påfund i kirkens traditioner og således finde tilbage til det centrale i kristendommen.

Den første reformatoriske dogmatik fra 1521, udarbejdet af Philip Melanchthon, hed karakteristisk nok Loci communes, som måske bedst kan oversættes med "Fælles anliggender". Det er derfor med rette, at Luther, Melanchthon og Calvin med flere andre er blevet kaldt the magistral Reformers, de læremæssige reformatorer. Alligevel kan man i et historisk perspektiv se reformatorernes søgen efter koncentrerede udtryk for kristendommens væsen som en forløber for den teologiske etos, der i løbet af 1700-tallet udvikler sig til ideen om protestantismen som en særlig udgave af kristendommen. Mens romersk-katolsk teologi traditionelt har søgt at udarbejde en teologisk fylde ( $\mathrm{fx}$ formuleret i store skolastiske summaer eller i velafbalancerede encyklikaer), har protestantisk teologi som regel stået for en teologisk koncentration om det væsentlige i kristendommen.

Protestantisme blev dermed en samlebetegnelse for den del af kristendommen, der er udgået fra 1500-tallets reformationsbevægelser Alligevel har protestantismens idé været omstridt lige fra begyndelsen og frem til i dag. Kronologisk kan man groft sagt skelne mellem den klassiske periode i reformatorisk teologi ca. 1520-1700, og nyprotestantismen fra 1700-tallet og fremefter. I den klassiske periode har vi først den formative periode ca. 1520-1560, hvori den reformatoriske teologi blev udviklet i prædikener, katekismer, skriftfortolkning, lejligheds- og stridsskrifter. Fra starten fik Luthers og Calvins skrifter en særlig normativ status. I forlængelse heraf udviklede der sig i perioden 1560-1700 en række forskellige ortodokse systemer, bundet til hver sin konfessionskirke (luthersk, calvinsk etc.) og med hver sine bekendelsesskrifter og katekismer. Det siger sig selv, at det i denne periode ikke var naturligt at bruge protestantismen som et fællesbegreb. Lutheranerne var $\mathrm{fx}$ i nadverteologi og liturgisk praksis i realiteten tættere på romersk-katolsk teologi end på calvinsk eller zwingliansk teologi.

Anderledes bliver det først $\mathrm{i}$ den periode, som Ernst Troeltsch i skriftet Protestantisches Christentum und Kirche in der Neuzeit (1906) døbte nyprotestantismen. Udviklingen hen imod nyprotestantismen begynder med den Westfalske Fred 1648, der afsluttede 30 års religionskrige. Herefter betegnes ikke bare lutheranere, men også calvinister og nonkonformister undtagelsesvis som protestanter. I skriftet Billedstormeren (Eikonoklastes) fra 1649 taler digteren John Milton om "the Protestant Religion both abroad and home", hvormed han som dissenter også lagde afstand til den etablerede engelske kirke. ${ }^{29}$

29. Se hertil Friedrich Wilhelm Graf, "Protestantismus II. Kulturbedeutung”, Theologische Realenzyklopädie Band 27 (Berlin: de Gruyter 1997), 551-580 (554). 
Tydeligvis begynder fællestrækkene imellem de protestantiske konfessioner nu at springe i øjnene, hvad der også afspejler datidens politiske realiteter, hvor protestantiske lande som England, Holland, Nordtyskland og Norden stod samlede imod en stærk katolsk kejsermagt med basis i Spanien, Frankrig, Italien og det sydlige Tyskland. Fælles fjender forener.

Senere opstod der en politisk interesse i en kirkelig forening af de protestantiske konfessionskirker. Tydeligst var dette i Tyskland, hvor der i Preussen i 1817 blev indført en unionskirke omfattende både lutherske og calvinske menigheder. Først hermed opstod tanken om en "protestantisk kirke" i sammenhæng med forestillingen om en særlig protestantisk mentalitet. Ingen ringere end nyprotestantismens fader, Friedrich Schleiermacher (1768-1834) gjorde sig fra starten til redskab for dannelsen af en preussisk unionsteologi. I Der Christliche Glaube $\left(1821 / 22^{1}, 1831^{2}\right)$ optræder lutherdommens og calvinismens bekendelsesskrifter som sideordnede. Samtidig formulerede Schleiermacher tanken om protestantismen som en særlig udformning af kristendommen, der adskiller sig fra den katolske kirke i synet på individets rolle i forhold til Gud:

I foreløbig form kan modsætningen mellem protestantisme og katolicisme formuleres på den måde, at mens protestantismen lader den enkeltes forhold til kirken afhænge af hans eller hendes forhold til Kristus, så lader katolicismen omvendt den enkeltes forhold til Kristus være afhængigt af hans eller hendes forhold til kirken. ${ }^{30}$

Ifølge Schleiermacher fjerner protestantismen kirken som den nødvendige mediator mellem den troende og Gud. Det kirkelige fællesskab bliver resultatet af, at det enkelte individ tror på Gud gennem Kristus, men kirken er ikke længere troens nødvendige forudsatning. Dermed åbnede Schleiermacher samtidig døren op for den mulighed, at kristendommen kan vokse ud over kirken. For hvorfor skulle individets gudsforhold ikke kunne realiseres uden for kirken? Dette havde også været Scheliermachers oprindelige udgangspunkt i skriftet Über die Religion. Reden an die Gebildeten unter ibren Verächtern fra 1799: "Den, der tror på et skrift, har ikke religion, men derimod den, der ikke har brug for noget skrift og sagtens selv kunne klare det". 31

30. Friedrich Schleiermacher, Der christliche Glaube nach den Grundsätzen der evangelischen Kirche im Zusammenhange dargestellt [18312], red. Martin Redeker (Berlin: De Gruyter 1960), Bd. I, 137 (\$ 31). Min oversættelse.

31. Friedich Schleiermacher, Om religionen. Taler til de dannede blandt dens foragtere, overs. Birgit Bergrensson i samarbejde med Theodor Jørgensen (København: 
Intetsteds bliver denne religiøse individualisme tydeligere end $\mathrm{i}$ G.W.F. Hegels (1770-1831) historiefilosofi. Her hedder det helt uden omsvøb og forbehold: "Dette er reformationens væsentligste anliggende: mennesket er bestemt til at være frit gennem sig selv." 32 Det er bemærkelsesværdigt, at reformationstidens væsentligste anliggende hermed bestemmes på en måde, som savner holdepunkt i reformatorernes skrifter, der nærmest siger det modsatte, nemlig at mennesket kun kan blive frit gennem Helligåndens gerning. Men i forlængelse af Hegel taler også den teologiske venstrehegelianer F.C. Baur (1792-1860) om modsætningen mellem katolske og protestantiske principper. Således står inden for protestantismen "subjektets autonomi i modsætning til al heteronomi i det katolske kirkebegreb”. ${ }^{33}$ Der forbliver en modsætning mellem troens frie selvbestemmelse i protestantismen og katolicismens krav om ydre lydighed. Protestantismen opfattes nu som en bevidsthedsform på kulturens arena uden noget bestemt indhold og uden nogen kirkelig identitet.

Førnævnte Ernst Troeltsch (1865-1923) var som historiker klar over, at den hegelske Luther-tolkning ikke var holdbar. Han erkendte, at reformationen har et Janus-ansigt: det ene peger bagud mod middelalderen, mens det andet kigger fremad og baner vejen for moderniteten. Troeltsch definerer ligefrem sin skelnen mellem gammelog nyprotestantisme ud fra, om protestantismen forudsætter en uniform konfessionskirke eller vokser ud over sin kirkelige skikkelse. Ifølge denne historiekonstruktion viser nyprotestantismen, at kristendommen har løsgjort sig fra sin historisk-kirkelige form. Troeltsch måtte derfor mene, at Friedrich Schleiermachers kirkelige unionsteologi var blevet stående på halvvejen mellem en kirkelig og en kulturel protestantisme. Men fælles var den hegelske og den schleiermacherske tradition om at lede efter protestantismens "principper".

Vi kan begynde med de to reformatoriske principper (skriften som det reformatoriske formalprincip og retfærdiggørelsen som det reformatoriske materialprincip), som de blev formuleret af formidlingsteologerne August Twesten og Wilhelm de Wette m.fl. midt i 1800tallet i forlængelse af Friedrich Schleiermacher. Også disse teologer

Aros 2010), 99. Oversat fra førsteudgaven 1799: "Nicht der hat Religion, der an eine heilige Schrift glaubt, sondern der welcher keiner bedarf, und wohl selbst eine machen könnte" (122). Den tyske tekst siger faktisk, at det religiøse menneske selv kunne lave sig en hellig skrift.

32. G.W.F. Hegel, Vorlesungen über die Philosophie der Geschichte [postum 1837] i: Sämmtliche Werke Bd. 11, ed. Hermann Glockner (Stuttgart: Bad Cannstadt 1971), 524: "Dies ist der wesentliche Inhalt der Reformation: der Mensch ist durch sich selbst bestimmt frei zu sein".

33. F.C. Baur, Die Epochen der kirchlichen Geschichtsschreibung (Tübingen 1852), 257, læst fra www.bibliolife.com/opensource. 
stillede sig til tjeneste for den preussiske Unierte Kirche, der blev etableret 1817. Som Jan Rohls nøgternt konstaterer: "Die Proklamierung eines protestantischen Prinzips dient dazu, hinter die konfessionellen Lehrdifferenzen zwischen Lutheranern und Reformierten zurückzugehen auf ein einheitliches Fundament". ${ }^{34}$

Men selv den principsøgende protestant har svært ved at lade principperne stå alene. Også i den dannede unionsteologi kom de fromme personer i centrum som en slags erstatnings-ikoner. Træder man ind i den imposante domkirke i Berlin, bygget af Kejser Vilhelm d. 2 og færdiggjort i 1905, ser man fra kirkegulvet to store statuer af Luther og Calvin stå på høje søljer op mod alterpartiet, som store keruber der bevogter indgangen til højaltret, hvor Kristus troner foroven - i baggrunden. Til venstre for Luther (set fra kirkerummet) står da en tilsvarende søljestatue af Zwingli, altså til højre for Luther, som var han hans højre hånd. Tilsvarende står til højre for Calvin (set fra kirken) Philipp Melanchthon, Luthers højre hånd, der dermed står som Calvins venstre hånd. Til trods for, at koreografien er noget ubehjælpsom, afspejler ikoniseringen meget godt unionsteologiens substantielle uklarhed. Tydeligvis er hensigten at koge det evangeliske anliggende ned til nogle få principper, som alle fire reformatorer velsagtens kunne blive enige om.

Nyprotestantismen fik to hovedformer, alt efter om den teologiske identitet knyttes til en kirkelig bevidsthed i forskellige udgaver af konservativ eller formidlende teologi, eller til en mere rendyrket protestantisk dannelseskultur. Men også i den konfessionelle teologi begynder man at definere protestantismen ud fra kortformler og principper. Schleiermachers elev og efterfølger August Twesten (17891876) indførte således begrebet om protestantismens to principper: skriften som formalprincip og retfærdiggørelsen ved tro alene som materialprincip, hvormed han mente at kunne formulere vekselvirkningen mellem den objektive side (skriftprincippet) og den subjektive side (trosprincippet) i protestantismen. 35 Lignende formuleringer finder vi også i højrehegelianismen hos fx Isaak August Dorner og vores egen H.L. Martensen. ${ }^{36}$

34. Jan Rohls, Protestantische Theologie der Neuzeit (Tübingen: Mohr-Siebeck 1997), Bd. I, 573.

35. De to principper formuleres mig bekendt første gang af August Twesten i Vorlesungen über die Dogmatik der evangelisch-lutherischen Kirche (Hamburg: F. Perth 1826), Bd. 1, 257-264, læst fra www.openlibrary.org.

36. H.L. Martensen, Den christelige Dogmatik (1849), udg. Alfred Th. Jørgensen (København: Gad 19045), 33: "Hvad Reformationen vilde, var hverken udelukkende det Objective eller det Subjective; det var den frie Forening af det Objective og det Subjective, af Troens Indhold og Troens Inderlighed” (\$21). En lignende position findes allerede hos Isaak August Dorner, "Das Prinzip unserer 
Selvom Albrechts Ritschl gjorde et forsøg på at forene den individuelle bevidsthed med den sociale ide om Guds rige (Unterricht in der christlichen Religion, 1874) og med rette påpegede det vilkårlige i distinktionen mellem reformationens material- og formal princip, så opererede også han med en ide om de reformatoriske principper, idet han bestemte Luthers anliggende som en løsning, der befinder sig mellem middelalderens og Andreas Osianders retfærdiggørelseslære. Om Luther hedder det, at han i en lang række udsagn udfolder den "grundsætning (Grundsatz), at den sande og virkelige erkendelse af Gud kun kan vindes gennem Kristus-åbenbaringen, kun i anerkendelsen af hans nåde og kun i udøvelsen af en dertil svarende tillid". ${ }^{37}$

Denne bestemmelse af forholdet mellem solo Christo og sola fiducia er i forhold til Luthers tekster en hel del mindre vilkårlig end det hegelske princip om menneskets selvbestemmelse. Men der er fortsat tale om en minimaliseringsbestræbelse, der holder sig kristendommens ydre livsytringer på afstand. På baggrund heraf er det som ovenfor sagt fristende at se protestantismens princip-tænkning som en særlig tidsbetinget refleks af den subjektivering af troen, der fandt sted i det nittende århundredes Tyskland ly af både Schleiermacher og Hegel, tilsat en god portion kontroversteologisk positionering i forhold til den romersk-katolske kirke. Hvad udadtil tabes, skal indadtil vindes.

\section{Eksklusivpartikler eller inklusivpartikler?}

Men der heller ingen tvivl om, at tanken om protestantismens principper har rødder længere tilbage. Vi vender os nu til de såkaldte reformatoriske "eksklusiv-partikler": Sola scriptura, solus Christus, sola gratia og sola fide. Sådanne formuleringer findes hver især som spidsformuleringer rundt om i Martin Luthers egne skrifter, men aldrig i rækkefølge, aldrig ud fra et ønske om bolstre en særlig protestantisk identitet - og aldrig som led i en teologisk minimalisme.

Kirche nach dem inneren Verhältniss der materialen und formalen Seite desselben zuieinander" (1841), udgivet i udvidet form i Dorner, Gesammelte Schriften aus dem Gebiet der systematischen Theologie, Exegese und Geschichte (Berlin 1883), 49-150.

37. Albrecht Ritschl, Die christliche Lehre von der Rechtfertigung und Versöhnung, Bd. 1 (Bonn: V. Marcus und E. Webers Verlag 19034), 209-210. Se hertil den instruktive analyse i Bo Holm, "Luthers kristologi og de 'protestantiske principper", i: Gudstankens aktualitet. Bidrag om teologiens opgaver og indhold og protestantismen indre spandinger, red. Else Marie Wiberg Pedersen m.fl. (København: ANIS 2010), 317-338 (325-328). 
Alligevel har Theodor Mahlmann i en indgående analyse dokumenteret, hvordan præsentationen af retfærdiggørelseslæren som articulus stantis et cadentis ecclesiae kan føres tilbage til 1600-tallet. Allerede Abraham Calov (1612-1686) skrev i sin Systema Locorum Theologicorum (1655-1677) i afsnittet 'Usus doctrinae' om retfærdiggørelseslæren, at denne også ifølge Luther selv var den artikel, som "kirken stod og faldt med, og af hvilken alene vi kan uddrage forskellen mellem lov og evangelium". ${ }^{38}$ Hermed tænkte Calov sandsynligvis på, at Luther i De Schmalkaldiske Artikler fra 1537 taler om retfærdiggørelsen hos Paulus (Rom 3,26) som "der erste und Häuptartikel": "Von diesem Artikel kann man nichts weichen oder nachgeben, es falle Himmel und Erden oder was nicht bleiben will". ${ }^{39}$ I sin lange redegørelse viser Mahlmann, hvordan de samme formuleringer bliver ved med at blive gentaget, og endda i stigende grad op igennem det 20 . århundredes Luther-forskning. I en helt ny undersøgelse har David C. Fink samtidig påvist, at selvom henvisningerne til retfærdiggørelseslæren som hovedartikel var udbredt i tiden efter Luthers og Calvins død, så viser de teologiske udfoldelserne heraf, at der var tale om højst forskellige forståelser af evangeliet blandt de reformatoriske teologer. ${ }^{40}$

Og hermed er vi tilbage ved det ved spørgsmålet, om den principialisering, som påbegyndtes i det 19. århundredes protestantiske teologi og videreførtes med den dialektiske teologi op igennem det 20. århundrede, er en deformationen af reformationen - eller en legitim videreførelse af Luthers anliggende. ${ }^{41}$ Det er betegnende, at selv en Luther-kender som Eberhard Jüngel i sin artikel om "Rechtfertigung" i Religion in Geschichte und Gegenwart ${ }^{4}$ har viet ikke mindre end tre

38. Abraham Calovius, Systema Locorum Theologicorum 12 vols (1655-1677), vol 10, 160-61: "ac B. [eato] Luthero dicente, [doctrina iustificationis] stantis et cadentis est ecclesiae, e quo solo discrimen Legis \& Euangelii addiscimus”. Citeret efter Theodor Mahlmann, "Die Rechtfertigung ist der Artikel, mit dem die Kirche steht und fällt'. Neue Erkenntnisse zur Geschichte einer aktuellen Formel”, i: Zur Rechtfertigungslehre in der Lutherischen Orthodoxie, ed. Udo Sträter (Leipzig: Evangelische Verlagsanstalt 2003), 241-281 (246).

39. Die Bekenntnisschriften der evangelisch-lutherischen Kirche. Herausgegeben im Gedenkjahr der Augsburgischen Konfession 1930 (Göttingen: Vandenhoeck \& Ruprecht 1967), 415.

40. David C. Fink, "Was there a 'Reformation Doctrine of Justification", Harvard Theological Review vol 103: 4 (2010), 205-235: "What emerged in the aftermath of the Reformation was not a simple dominant orthodox view which carried the field, but rather multiple competing orthodoxies, each one with its own Gospel” (235).

41. Peter Widmann, "Reformation og deformation", Dansk Teologisk Tidsskrift 73:4 (2010), 243-252. 
spalter til eksklusivpartiklerne. ${ }^{42}$ Artiklen indledes med en vis bravour (gengivet på tysk for at fastholde stemningen): "Die Wahrheit der Rechtfertigungslehre hängt an den vier reformatorischen Exklusivpartikeln 'solus Christus', 'sola gratia, 'solo verbo' und 'sola fide'”. Endvidere hører vi, at adverbiet "alene" drejer sig om " $i$ en helt bestemt henseende at udelukke mennesket for på rette måde at inddrage mennesket i sin retfærdiggørelseshændelse". Dette udfoldes da som følger: Solus Christus betegner en udelukkelse af alle andre mediatorer (helgener, Jomfru Maria eller kirken), idet Kristus alene er trådt i alle menneskers sted - hvorved han også har inkluderet dem i korsbegivenheden. På samme måde udelukker sola gratia menneskets egne fortjenester, idet retfærdiggørelsen er "en betingelsesløs guddommelig gave", der dog giver plads for "menneskets glæde over sin retfærdiggørelse" (sic!). Solo verbo betegner tilsvarende, at retfærdiggørelsen "sættes i værk gennem en verbalt udfoldet akt af Guds retfærdighed". Jüngel må dog tilføje, at sakramenterne ikke hermed er udelukkede; blot er de "intet andet end 'visibile verbum", altså en blot og bar anskueliggørelse af evangeliets ord. Endelig har vi sola fide, som ifølge Jüngel betyder, at for så vidt som mennesket selv aktivt bliver inddraget i "retfærdiggørelseshændelsen", så sker dette "som troende og kun som troende".

Hvad skal man sige til sådanne udredninger? Det første, man må sige, er, at der er tale om nogle voldomme abstraktioner. Sådanne abstraktioner kan naturligvis være nyttige af pædagogiske hensyn. Men de kan også hindre en nærmere forståelse af sagen, hvorved formuleringerne ender med at blive ganske upædagogiske. Hvad sker der $\mathrm{fx}$, når Luthers tale om sola scriptura bliver generaliseret til et solo verbo? Der sker en vældig interesseforskydning fra skriftens ord til "retfærdiggørelseshændelsen" som en "verbal sproghandling", der så eventuelt $\mathrm{i}$ anden hånd kan "anskueliggøres" i dåben og nadveren. Vi er her temmelig langt væk fra den protestantisme med kød og blod, som vi fandt oven for hos Luther. Her var der forskelle på dåbens og nadverens betydning, idet dåben drejer sig om troen, mens nadveren drejer sig om kærligheden. Vi så også, at der hos Luther ikke findes noget belæg for at modstille Kristus og kirken. Nærmest tværtimod, eftersom "Kristus og hans hellige" altid hænger sammen i kirkens legeme, hvor Kristus er hovedet og menigheden hans lemmer. Og der er intet belæg for at sige, at mennesket kun inddrages i Kristus-forholdet gennem troen og ikke gennem håbet og kærligheden, eftersom Luther utrætteligt fremhæver, at troen ikke kan eksistere uden kærligheden.

42. Eberhard Jüngel, "Rechtfertigung IV. Dogmatisch", RGG 4 (Tübingen: MohrSiebeck 2004), 111-17 (om eksklusivpartiklerne, se 114-116; alle citater herfra). 
Der findes ganske enkelt ikke hos Luther nogen tale om, at et kristenmenneske kan være en troende solist uden en menighed. Der er heller ingen forestilling, at mennesket kan være en "kun troende" uden håbet og uden kærligheden.

Min modtese vil her være, at de såkaldte "eksklusivpartikler" ikke var ment som eksklusivpartikler, men snarere som inklusivpartikler. Der var for Luther tale om en prioritering, idet $\mathrm{fx}$ kærligheden gror ud af troen, ligesom kirken kun er, hvor Kristus er. Men der var for ham intet ønske om at foretage en eksklusion af kærligheden fra troens domæne, en eksklusion af kirken fra ordets domæne, en eksklusion af Kristi legeme fra Kristus som kirkens hoved, en eksklusion af traditionen fra skriftens domæne. En sådan skematiserende tænkning i domæner var aldeles fremmed for Luther. Det var sansen for prioriteringer derimod ikke. Rigtigt er det derfor, at Luther sagde skriften alene i et opgør med selvbestaltede kirkelige autoriteter, og rigtigt er det, at han råbte Kristus alene vendt mod lovens tyranni, og rigtigt er det, at han insisterede på nåden alene i et opgør med enhver tale om menneskets egne selvstændige bidrag til frelsen, og rigtigt er det endelig også, at Luther med troen alene markerede, at det ikke er menneskets evne til at lade sig gennemstrømme af Gud kærlighed, der gør det acceptabelt i Guds øjne, men troen, der tillidsfuldt tror, at Kristus har skænket det fuldgyldige offer, der gør andre ofre overflødige (bortset fra lovprisningens takoffer).

I denne helt præcise forstand kan man med en vis historisk ret tale om polemisk motiverede eksklusivartikler. Men der er ikke tale om, at evangelisk teologi kan sættes på korte formler, og at alt dermed skulle være sagt. Terminologien med de fire eksklusivpartikler hører hjemme i 1800-tallets konglomerat af nykonfessionalisme og nyprotestantisme, hvorefter ideen om en firepunkts-protestantisme tankeløst er blevet videreført op igennem det 20. århundrede. Men når Luther anvender solus-termerne, anvendes de som sagt altid som inklusivpartikler: Kristus inkluderer altid både Faderen og Helligåndens samfund. Ordet inkluderer altid skriftens mange ord og sakramenternes nådemidler. Kristi nåde inkluderer altid Kristus som gave, der indgives den troende. Og troen inkluderer altid håbet og kærligheden.

\section{Afslutning}

Jeg kan ikke se rettere, end at den protestantisme, der har valgt at definere den kristne tro ud fra principper snarere end ud fra kristendommens primære livsytringer, har ført til en betydelig trivialisering af reformationens anliggende. Formuleringen af protestantismens 
principper har muligvis givet god pædagogisk mening i en kulturel kontekst, hvor både teologer og lægfolk i forvejen kendte de bibelske traditioner og kirkens almindelige liv, måske endda til overflod. Man kan sagtens forestille sig den befrielse, det har været at fastholde grundprincipper for orienteringens skyld, og at insistere på Kerygmaet over for en alt for påtrængende kirkelighed. Sådan var det endnu i 1920 'erne. De dialektiske teologer og herhjemme Tidehvervs-tilhængerne kom alle fra en overbelastet pietisme, som princip-tænkningen og reduktionsformlerne var velegnede til at overvinde.

Men vi lever ikke længere i en kulturel situation, hvor kirken opleves som særligt påtrængende af den simple grund, at sekulariseringen er kommet imellem. Dermed kommer principperne til at stå som et lærestof af temmelig abstrakt art (som illustreret af Jüngels redegørelser). De protestantiske principper synes at have tabt deres pædagogiske funktion, fordi principperne ikke længere virker som orienterende, men snarere som desorienterende abstrakter. I den forstand mener jeg, at de protestantiske princippers tid er fordi. I dag drejer det sig om at genvinde sansen for kristendommens elementære indhold og de kirkelige livsytringer, som man ikke kan tænke væk fra kristendommen uden at tænke kristendommen væk. Kristendommen findes nu engang kun som levet religion, ikke som en abstraktion.

Men hvis reformationen skal fortsættes, er det ikke tilstrækkeligt at vise bagud og minde om, hvad der er gået tabt. Luthers teologi kan netop ikke tages som et fait accompli, der har det rigtige svar på alle vor tids spørgsmål. Opgaven må være at lytte til den levende kristne tradition og så tage den risiko på sig at deformere kristendommen ved at fortolke denne på ny. Her er der fortsat en reformatorisk impuls at lytte til, både for at lytte en ekstra gang og for at tage alle de nye spørgsmål op, der giver sig af dagens kulturelle situation: forholdet til en sekulariseret offentlighed og en selvsekulariseret kirke, forholdet til naturvidenskaberne og naturalismen, og forholdet til de andre levede religioner, som ikke er kristne og slet ikke ønsker at være det. ${ }^{43}$ Når alt kommer til alt var det disse spørgsmål, som nyprotestantismens teologer havde mod til at rejse. Om de så gjorde det med tilstrækkelige teologiske ressourcer i behold, kan derimod diskuteres.

Men kun den, der risikerer en deformation af reformationen, kan føre reformationen videre.

43. Se hertil Werner Jeanronds efterfølgende artikel, "Ecclesia semper reformanda: Protestant Principle and Church Renewal", Dansk Teologisk Tidsskrift 2010:4, 271-281. 